\title{
O SIONISMU A OBNOVĚ ŽIDOVSTVÍ V PŘEDDIALOGICKÉM DÍLE MARTINA BUBERA ${ }^{1}$
}

L'UBOMÍR ZVADA, Katedra politologie a evropských studií, Filozofická fakulta, Univerzita Palackého v Olomouci, Olomouc, ČR

ZVADA, L':: On Zionism and the Jewish Renaissance in Martin Buber's Pre-dialogical Thoughts

FILOZOFIA, 75, 2020, No 6, pp. 490 - 499

This article explains Martin Buber's pre-dialogical philosophy. In this paper, the author analyzes key thoughts expressed by Martin Buber on Judaism and Zionism. This essay mainly focuses on Buber's thinking about the concept of the socalled 'Jewish Renaissance', which Buber discusses in many of his essays, articles and especially in his book entitled Three speeches on Judaism. This is Buber's most important work concerning Judaism written during his pre-dialogical period.

Keywords: Martin Buber - Philosophy of Religion - Philosophy of Judaism - Jewish Renaissance - Zionism

Martin Mordechai Buber patřil mezi nejvlivnější židovské myslitele dvacátého století, ne-li vůbec, a byl jedním z nejvýraznějších představitelů tzv. filozofie dialogu. Zájem o Bubera je nekončící, což dokládá bohatý zahraniční diskurz, který neustále reflektuje a promýšlí jeho dílo (Brody 2018, Shonkoff 2018, Mendes-Flohr 2019). Navíc v roce 2019 bylo dokončeno kritické vydání Buberova díla Martin Buber Werkausgabe, které začalo vznikat již v roce 2001 a čítá na 21 svazků. ${ }^{2}$ Domácí diskurz, snad jen s výjimkou prací Petra Šajdy (Šajda 2011, 2013, 2013a, 2020), se téměř výhradně orientuje na Buberovu recepci jeho dialogického odkazu (Poláková 1993, 1995; Bizoň 2014, 2016, 2017) a opomíjí tzv. předdialogické období Buberovy tvorby, které však, jak poznamenává P. Šajda, výrazně „,formovalo např́ílad určitá specifika důležitá pro pochopení vývoje Buberových vizí vztahu náboženství k etice a politice“ (Šajda 2013,

\footnotetext{
${ }^{1}$ Autor by na tomto místě rád poděkoval anonymním recenzentům za cenné komentáře, a také svým kolegům Jiřímu Lachovi, Kateřině Hojgrové z Katedry politologie a evropských studií a Ivaně Grenové z Katedry germanistiky Univerzity Palackého v Olomouci.

${ }^{2}$ Prvním svazkem vydaným v roce 2001 byl svazek Frühe kulturkritische und philosophische Schriften 1898 - 1924. Tím posledním z loňského roku je svazek Schriften zur zionistichen Politik und zur jüdisch-arabischen Frage.
} 
156). Autor textu si klade za cíl představit poněkud opomíjené téma předdialogické Buberovy tvorby, ${ }^{3}$ jenž reflektuje jeho myšlenky k židovstvíi ${ }^{4}$ a sionismu. Autor přiblíží čtenáři stěžejní myšlenkový koncept Buberovy rané tvorby, kterým je tzv. obnova židovství, ${ }^{5}$ prezentovaný především v díle Tři řeči o židovství, ${ }^{6}$ ale také v celé řadě jiných, méně známých esejí, které Buber publikoval v první dekádě minulého století, souhrnně vydaných v roce 1916 v díle Židovské hnutí: sebrané projevy a články $1900-1915 .^{7}$

\section{Buberova recepce židovství a sionismu v období fin de siécle}

Interpretace rané náboženské a politické filozofie Martina Bubera se de facto odehrává na pozadí kvintesenciální debaty evropského židovství na počátku 20. století, která se dotýká samé duální povahy židovství, jenž v praktické rovině ztělesňovala klíčová debata o budoucnosti židovského národa uvnitř sionistického hnutí mezi Theodorem Herzlem a Ahadem Ha'amem.

Theodore Herzl, otec sionistické myšlenky a hlavní představitel tzv. politického sionismu, formuloval základní teze potřeby vytvoření židovského státu v díle Židovský stát (1896), ${ }^{8}$ které spočívaly v následující argumentaci: „my (Židé - pozn. autora) jsme se vždy a všude pokoušeli v dobrém úmyslu splynout s národy, které nás obklopovaly, a přitom zachovat svoji víru. Nebylo nám to však umožněno. Marně jsme patrioty a přinášíme nejvyšší oběti, marně se snažíme v umění, vědě nebo obchodu. Ve státech, ve kterých žijeme, jsme jenom cizinci“" (Herzl 2009, 47). Herzlova vize, jež se opírala o politické vyjednávání a ustavení židovského státu, který brala výhradně jako politický cíl, se stala neakceptovatelnou zejména pro východoevropskou židovskou populaci. Ahad Ha'am, lídr východoevropského židovství ve své eseji Židovský stát a židovský problém (1897) vinil T. Herzla z nepochopení židovského problému. Zatímco pro Ostjuden měl sionismus přinést řešení především existenčních problémů,${ }^{9}$ tak Westjuden očekávalo od sionismu řešení problémů existenciálního charakteru. ${ }^{10}$ Normativním

\footnotetext{
${ }^{3}$ Období tzv. předdialogické tvorby je u Bubera nejčastěji vymezené lety 1897 - 1916 (Šajda 2013, $156-157)$

${ }^{4}$ Autor chápe pojem židovství v širším významu, který v sobě zahrnuje židovskou kulturu, umění a jazyk, tradice či náboženství (nem. Judentum), ne v úzkém vymezení židovství, které ho asociuje primárně jen skrze judaismus.

${ }^{5}$ Buber užívá pojmu Jüdische Rennasaince (nem).

${ }^{6}$ Buber, M. (1912): Tři řeči o židovství. Praha: Spolek židovských akademiků Theodore Herzl. $S$ předmluvou Arnošta Kollmanna.

${ }^{7}$ Buber, M. (1916): Die Jüdische Bewegung - Gesammelte Aufsätze und Ansprachen 1900 - 1915. Berlin: Jüdischer Verlag.

${ }^{8}$ Celý název Herzlova díla zněl: Der Judenstaat: Versuch einer modernen Lösung der Judenfrage.

${ }^{9}$ Zejména těch, které se týkají ekonomického a politického postavení Židů.

${ }^{10}$ Krize spojená s úpadkem náboženské afinity a nástup kosmopolitismu, pozitivismu atp.
} 
cílem A. Ha'ama a skupiny tzv. kulturních sionistư ${ }^{11}$ mělo být založení skutečného židovského státu (Jüdischer staat), nikoliv státu pro Židy (Judenstaat), tak jak jej nastínil T. Herzl ve svém stejnojmenném díle (Ha'am in Kohn 1962, 78 - 79). Buber se v této kruciální debatě postavil za vizi A. Ha’ama a vytvoření židovského státu.

Pro Bubera znamenalo objevení sionismu něco, co „znovuobnovilo jeho vztah k společenství (...) zakořeněnost, př́slušnost, celistvost“" (Buber 1994, 35 - 36). Období fin de siécle, jak jej Buber reflektoval po svém prríchodu z Galície do Vídně či Berlína, bylo dle Bubera pro Westjuden „obdobím bez židovství; bez pravého lidstva; bez př́tomnosti božského“ (Buber 1994, 35). Buber spatřoval v sionistickém hnutí možnost, jak židovství vyvést z hluboké morální krize, která souvisela s úpadkem náboženské afinity a nadměrnou asimilací do většinové společnosti nově se tvořících evropských národů.

Buberova recepce sionismu navazovala na kulturně-náboženskou dimenzi, kterou prezentovali ve svých dílech nejen A. Ha'am, ale již dříve Leo Pinsker, či Moses Hess, dle Bubera „skuteční sionističtí myslitelé“ (Buber 1973, 111). Nakonec, sionismus nebyl pro Bubera jen jedním z mnoha nacionálních hnutí té doby, nýbrž představoval př́pad sui generis. Diferenční znak sionistického hnutí byl dle Bubera skrytý v jeho samotném názvu. Etymologicky se vázal na konkrétní geografický název - horu Sion, nacházející se na území Eretz Jisrael ${ }^{12}$ (Buber 1973, xvii - xviii). Navíc židovské národní hnutí se na rozdíl od jiných nacionalismů nedefinovalo z povahy své protonárodní entity, protože Židé nereprezentovali homogenní skupinu žijící na jasně geograficky vymezeném území, sdílející společné kulturní tradice a zvyky.

\section{Buberova vize sionismu a soudobá kritika hnutí}

Vztah Bubera a hlavního proponenta politického sionismu T. Herzla byl komplikovaný. Nejvýstižněji ho Buber popsal krátce po Herzlově smrti v roce 1904 v článku s názvem Theodor Herzl ${ }^{13}$ či v článku Herzl a historie, ${ }^{14}$ ve kterých vinil Herzla

\footnotetext{
${ }^{11}$ Skupinu kulturních sionistů tvořili kromě M. Bubera zejména Ahad Ha’am, Berthold Feiwel, Nathan Birnbaum, Albert Einstein, či Judah Leon Magnes. Obrovský vliv měla tato skupina intelektuálu na pražský židovský sionistický spolek Bar Kochba a jeho členy, především pak na Hanse Kohna, Samuela H. Bergmanna, Felixe Weltsche, Roberta Weltsche (KIEVAL, J. H. 2011, 143 - 233).

12 Eretz Jisrael, Eretz Israel - území Svaté země, biblického státu Izrael. V roce 1900, když Buber esej psal, bylo toto území součásti Osmanské říše. Po 1. světové válce, až do vzniku státu Izrael $\mathrm{v}$ roce 1948, bylo území pod kontrolou Velké Británie.

13 Text byl publikován v roce 1904. Citováno z Buber. M. (1904): Theodor Herzl. In: Buber, M. (1916): Die Jüdische Bewegung: Gessamelte Aufsätze und Ansprachen 1900 - 1915. Berlin: Jüdischer Verlag, 138 - 152. K Buberově korespondenci s T. Herzlem podrobněji např́klad Glatzer, N., Mendes-Flohr (1991): The Letters of Martin Buber. A Life of Dialogue. New York: Schocken Books, $226-311$.

${ }^{14}$ Text byl publikován v roce 1904. Citováno z Buber. M. (1904a): Herzl und die Historie. In: Buber, M. (1916): Die Jüdische Bewegung: Gessamelte Aufsätze und Ansprachen 1900 - 1915. Berlin: Jüdischer Verlag, 153 - 174.
} 
z opomíjení a nepochopení odkazu východoevropského židovství. Buber považoval Herzla za „západního Žida, kterému se nedostalo židovské výchovy v mladém věku, (...) nikdy nepoznal židovské masy, neměl židovské vědomí, (...) byl sice úplným člověkem, ale ne úplným Židem“ (Buber 1904, Buber 1904a, 154).

Ke způsobu, jakým bylo sionistické hnutí vedeno, se Buber vyjádřil $\mathrm{v}$ jednom ze svých prvních textů v pozici šéfredaktora listu Die Welt, do které ho dosadil sám Herzl. V eseji Práce v přitomnosti ${ }^{15}$ Buber kritizoval bezmyšlenkovitost lídrů hnutí a také sílící tendence k prosazování Herzlovy politické vize sionismu navzdory skutečnosti, že v hnutí existovala celá řada ideologických frakcí, které politický sionismus odmítaly a nabízely relevantní alternativy (Buber 1901). „Program aplikovaného sionismu“, který Buber ve svém textu nastínil, měl vést $\mathrm{k}$ větší decentralizaci uvnitř hnutí, uznání myšlenkové heterogenity a k větší participaci s jinými frakcemi uvnitř hnutí. Dle Bubera měl sionismus „,vychovávat pedagogy, utvrzovat nejisté; měl být prostorem pro seberealizaci a měl přimět $\mathrm{k}$ návratu ty, jež hnutí opustili““ (tamtéž, 21). Pro Bubera bylo propojení různých názorových proudů židovství conditio sine qua non, jenž přivede Židy ke skutečné „duchovní svobodě a nezávislosti“ (tamtéž, $21-22$ ).

V dalším ze svých textů Tviorci, lidé a hnuti ${ }^{16}$ Buber upozorňoval na skutečnost, že vedení sionistické organizace je jeho největší slabinou, protože v něm absentuje př́tomnost tzv. Tvưrce, jak ho ve svém textu Buber operacionalizoval. Tvưrce by neměl být podle Bubera ani př́lišným intelektuálem, ani umělcem. Intelektuál je až př́iliš logický, systematický, a nemá v sobě esenci tajemství, zatímco umělec, který sice potřebnou esenci tajemství má, není rétoricky zdatný, aby tuto esenci přenesl na zbylé členy uvnitř hnutí (Buber 1902, 68 - 69). Buber viděl absenci propojení Tvi̊rce a lidu mimo jiné v tom, že sionismus reagoval jen na vnější podněty a scházelo mu imanentní propojení mezi prožíváním a činy národa (tamtéž, 75). Buber definoval největší tragédii sionismu ve skutečnosti, která tkví v tom, „že Tvưrci jsou odtrženi od přirozeného života společenství, ze kterého pocházejí (...) mluví jiným jazykem než masy, ze kterých vzešli (...) mají jinou vůli a žádný most nevede od nich k tamnímu lidu“ (tamtéž, 76).

\footnotetext{
${ }^{15}$ Esej Gegenwartsarbeit publikoval Buber v židovském sionistickém listu Die Welt 8. února 1901. Citováno z Buber, M. (1901): Gegenwartsarbeit. In: Buber, M. (1916): Die Jüdische Bewegung: Gessamelte Aufsätze und Ansprachen 1900 - 1915. Berlin: Jüdischer Verlag, 17 - 22.

${ }^{16} \mathrm{~V}$ něm. Die Schaffenden, das Volk und die Bewegung. Text byl publikován v roce 1902. Citováno z Buber. M. (1902): Die Schaffenden, das Volk und die Bewegung. In: Buber, M. (1916): Die Jüdische Bewegung: Gessamelte Aufsätze und Ansprachen 1900 - 1915. Berlin: Jüdischer Verlag, $68-77$.
} 
V textu Sionistická politika ${ }^{17}$ posléze Buber prezentoval konkrétní piliúre, o něž by se měla sionistická politika opírat. Byly jimi „propaganda, vyjednávání a osídlováni", přičemž všechny tyto pilíře měly být komplementárně propojeny (Buber 1903a, 109). Buber odlišoval dvojí povahu propagandy, interní a externí. Externí pojil s vyjednáním mezinárodní podpory pro „židovskou věc“ u klíčových mocností. Pro Bubera však byla daleko důležitější vnitřní propaganda, protože vycházel z premisy, že „vedoucími osobnostmi dneška jsou lidé zítřka“ (tamtéž, 111). Úspěch prvních dvou piliriru je dle Bubera podmíněn úspěšným osídlováním palestinského území, na kterém má být židovský stát vybudován. Vytvoření státu mělo v Buberově vizi podnítit evropské židovství zůstávající v diaspoře $\mathrm{k}$ intenzivnější a masivnější migraci do Palestiny. „Kolonizační politika“ v Buberově představě neznamenala „,malou kolonizaci“ (Kleinkolonisation), nýbrž mělo jít o kolonizaci v co možná největší míře. Hlavním úmyslem této politiky byla podpora vytvoření „duchovního centra v Palestině“, tak jak jí předestřel A. Ha'am (tamtéž, 120).

\section{O renesanci, chceme-li, o obnově židovství}

Samotný koncept znovuzrození, chceme-li obnovy židovství, Buber poprvé načrtnul $\mathrm{v}$ textech Židovská renesance ${ }^{18}$ a Renesance a hnutí. ${ }^{19}$ Buber v nich reflektoval vzestup nacionálních idejí z přelomu devatenáctého a dvacátého století, které zasáhly také židovský národ, a vnímal je jako „epochální událost, sebereflexi lidských duší“ (Buber 1900, 8). Pro Bubera představoval sionismus pouze formu, čili způsob, jakým se nová lidská kultura oznamuje židovskému lidu. Obsahem, kterým by měl židovský národ a židovské nacionální hnutí tuto formu naplnit, pak bylo něco, co Buber nazval znovuzrozením nebo renesancí židovství (Jüdische Rennasaince).

Vzorem pro obnovu židovského národa mělo být období italského Quattrocenta, tedy období italské renesance ze 14. století a jeho myšlenkový a kulturní odkaz. Toto období pro Bubera neznamenalo návrat $\mathrm{k}$ antickým kořenům, nýbrž jejich znovuzrození. Znovuzrození antických ideálů v př́padě italského Quattrocenta znamenalo zrození společenství, které se dovolávalo antických ideálů, odmítalo ranou dialektiku, scholastiku či středověký asketismus, a obrátilo svoji pozornost k př́rodě a svobodě lidského jedince (Buber 1900, 9 - 10). Navzdory tomu, že Buber vyzýval tehdejší židovství

${ }^{17}$ Stat' Zionistiche politik Buber napsal a publikoval v roce 1903. Citováno z Buber. M. (1903a): Zionistiche Politik. In: Buber, M. (1916): Die Jüdische Bewegung: Gessamelte Aufsätze und Ansprachen 1900 - 1915. Berlin: Jüdischer Verlag, 109 - 121.

${ }^{18}$ Text Jüdische Rennaisance publikoval již v roce 1900. Citováno z Buber, M. (1900): Jüdische Rennaisance. In: Buber, M. (1916): Die Jüdische Bewegung: Gessamelte Aufsätze und Ansprachen 1900 - 1915. Berlin: Jüdischer Verlag, 7 - 16.

${ }^{19}$ Text Rennaisance und Bewegung publikoval Buber posléze v roce 1903. Citováno z Citováno z Buber, M. (1903): Rennaisnce und Bewegung. In: Buber, M. (1916): Die Jüdische Bewegung. Gessamelte Aufsätze und Ansprachen 1900 - 1915. Berlin: Jüdischer Verlag, 95 - 108. 
k napodobení italské renesance a k znovuzrození „zlatých věkư“ židovské historie, explicitně nepředložil, která historická období by měla reprezentovat pomyslné ,„̌idovské Quattrocento“. Tato období prèedstavil a nastínil až ve svém pozdějším textu Renesance a hnutí v období, kdy již ukončil spolupráci se sionistickým hnutím a dva roky se intenzivním, asketickým způsobem života věnoval studiu chasidismu. Chasidismus a jeho důraz na existenciální prvky religiozity se měl podle Bubera stát prvním pilířem, který je nutný k znovuzrození a proměně evropského židovství. Druhý piliřr měla představovat haskala, tedy odkaz židovského osvícenství (Buber 1903, 95).

Znovuzrození či obnova židovství představovala pro Bubera ideu, která v sobě komplementárně propojila narativ duální židovské identity. Nauka chasidismu typická pro Ostjuden a odkaz židovského osvícenství jakožto vklad Westjuden. Zatímco cadikim $^{20}$ měli do života Židů navrátit Boha, jenž se stane jejich každodenní součástí, tak hlavním cílem maskilim ${ }^{21}$ mělo být znovuzrození zájmu Židů o židovskou kulturu a hebrejský jazyk.

Otázce židovské renesance, či jiným otázkám souvisejícím se židovstvím, se pak Buber věnoval ve svých třech přednáškách, které pronesl před pražským sionistickým spolkem Bar Kochba v Praze. Jejich souborné vydání nesoucí název Tř́ řeči o židovství představuje pomyslný vrchol Buberovy tvorby, dotýkající se problematiky židovství a sionismu v předdialogickém období jeho tvorby.

\section{O významu židovství pro Židy}

Ve své první přednášce před pražským auditoriem s názvem $O$ významu židovství pro Židy nabídl Buber svůj filosofický vhled do historie židovského lidu s cílem odpovědět na dotaz „Proč nazýváme se Židy? “ (Buber 1912, 13). K zodpovězení takto položené otázky přistoupil autor $\mathrm{v}$ její celistvosti a nabídl odpověd” nejen židovi, ale rovněž Židovi, tedy představiteli náboženské skupiny a představiteli národního etnika. Buber se ve svém přemýšlení odmítal zabývat vnějšími formami projevů židovské víry a národního cítění, a dožadoval se definování samé vnitřní podstaty žida / Žida, přičemž hlavní část své první přednášky věnoval hledání kvintesence, která spojuje představitele etnické skupiny.

Buber odmítal akceptovat židovskou víru jako projev dovolávající se své dědičné povahy (aus Erbgewohnheit), nýbrž ji definoval skrze její životní, vnitřní skutečnost (aus Wirklichkeit). Obdobnou analogii předkládá Buber i při hledání vnitřní podstaty etnického významu židovství. Židovská národní existence nesmí podle Bubera čerpat svou afinitu ze zkušenosti s nežidovským světem. Čerpání a odvozování své etnické

\footnotetext{
${ }^{20}$ hebr. cadikim - nositelé chasidské nauky; jednotní číslo cadik.

${ }^{21}$ hebr. maskilim - nositelé odkazu židovského osvícenství, haskaly; jednotní číslo maskil.
} 
př́slušnosti z této zkušenosti vytváří dle Bubera jen tzv. židovství ze vzdoru (Trotzjude), a ne židovství autonomní skutečnosti (tamtéž, 15).

Buber vyzýval židovské společenství k objevení trvalé substance, která bude definovat jeho vnitřní podstatu. Objevení trvalé substance předpokládá opuštění vnějšího kosmu a subjektivní zájmovou redefinici. Jakmile žid opustí svůj vnější kosmos, ponoří se do svého duchovního Já, naváže intimní, personální vztah s Bohem a objeví trvalou substanci sebe sama. Obdobná analogie platí také v př́padě hledání trvalé substance etnického Žida a židovského národa (Buber 1912, 15). Vnější kosmos každého Žida je podle Bubera utvářen dvěma velkými okruhy společenství - domovinou a lidstvím, přičemž na utváření pocitu sounáležitosti se společenstvím širším, tedy lidstvím, se podílejí především trř konstantní elementy zažitého: domov (Heimat), řeč (Sprache), mravy (Sitte) (tamtéž, 15 - 16). Konstantní elementy zažitého tvoří podle Bubera jen vnější kosmos Já každého Žida, na kterém uvázne většina Židů. Objevení trvalé substance a pravé podstaty etnického židovství předpokládá opuštění výše zmíněných konstantních elementů žitého a redefinici poznávání vnitřního Já každé personality, jenž přinese poznání konstantní existence (eine konstante Existenz), která tvoří základ konstantního bytí. Zatímco okolní svět je pro Bubera jenom „světem dojmů a vlivư“, vnitřní svět je „světem substance“. Trvalou substancí každého etnického Já je pak podle Bubera „společenství krve“, které má každé židovské Já „objevit v trvání své nekonečné minulosti“ (tamtéž, 16). Buberovou optikou může dojít k renesanci židovství a k jeho znovuzrození jen po objevení a pochopení významu pokrevní sounáležitosti se židovským národem, protože jen tak se může zrodit židovství budoucnosti.

\section{Židovství a lidstvo}

Ve své druhé přednášce, kterou Buber pronesl v Praze o rok později, se zaměřil na historii židovství, vztah židovského národa $\mathrm{k}$ jiným národům a k poslání židovství ve světě. Buber svojí analýzou židovských dějin nabídl odpověd' na otázku postulovanou $\mathrm{v}$ úvodu ,K čemu lidstvo potřebovalo, potřebuje a v celé své budoucnosti bude potřebovat židovství?“ (Buber 1912, 25). Zodpovězení výše načrtnuté otázky determinoval Buber akceptací předpokladu, že židovství je nejen fenoménem duálním, ale také polárním. ${ }^{22}$ Největší problém židovství, historický i soudobý, tkví dle Bubera v jeho záhadném a hrozivém, ale zároveň kreativním rozporu samotné existence. Jak Buber předkládá: „osudem židovství je to, že to nejvyšší z něho je vázané na to nejnižší; to nejvznešenější na to nejpodlejší“. Dějiny židovského národa jsou dějinami, které jsou na jedné straně plné „,podlých hráčů a zrádců“, na straně druhé místem „,proroků a vykupitelü“ (Buber 1912, 25 - 26).

${ }^{22}$ Více k dualitě a polaritě „židovské duše“ např. v eseji Two Foci of Jewish Soul (Buber 1948, 28 - 41). 
Když Buber předkládá vysvětlení polarity židovské duše, nelíčí ji jako negativní fenomén, právě naopak. Polarita židovství je dle Bubera jednotícím elementem židovských dějin, jelikož byla židovstvím přetavená hned do několika jednoticích idejí (tamtéž, 30). Biblická idea jediného, transcendentného Boha, díla talmudistů, mystika kabaly, spiritualita chasidismu, či život a dílo Barucha Spinozy znamenají pro Bubera tzv. pozitivní dějiny židovství; dějiny, které mají sloužit jako vzor na cestě ke znovuzrození židovství. Tyto židovské dějiny stojí v opozici vůči dějinám galuthu, odkazujícím na nemocný, ubohý, pokřivený židovský svět plný abstrakce (Buber 1912, 31 - 33).

Nejzásadnější př́nos židovství pro lidstvo jako takové tkví v židovském poslání neustále a opakovaně konfrontovat svět s požadavkem jednotnosti. Obzvláště to pak pro židovství platí v době, když se svět nachází na pomyslných křižovatkách dějin, tak jak tomu bylo na přelomu 19. a 20. století.

\section{O obnově židovství}

Ve své posledním projevu se Buber zaměřil na samotné znovuzrození, resp. obnovu židovství. Poslední řeč podrobil pečlivé analýze ve své studii již P. Šajda, který se zaměřil na Buberovu operacionalizaci klíčových pojmů jeho poslední přednášky; pojmů relativní a absolutní. P. Šajda ve svém př́spěvku poukazuje na to, že Buber se užíváním výše zmíněných pojmů přihlásil $\mathrm{k}$ chápání těchto pojmů $\mathrm{v}$ tradici sémantiky jazyka, která jde za prací filozofa Sörena Kierkegaarda. Šajda poznamenává, že tato skutečnost „dokazuje Kierkegaardův vliv na klíčové pojmy Buberovy předdialogické filozofie židovství“ (Šajda 2013a, 6). Jakým způsobem se Buber vztahoval k těmto pojmům a jakou roli zastávaly pojmy relativní a absolutní v procesu obnovy židovského národa?

Relativní život národa je pro Bubera ztělesněn v prchavosti všedního dne, jenž přináší $n$ nahodilých situací, nebo střídání jednotlivých generací (Buber 1912, 42). Relativita každého národa je tak zakořeněna v partikulárnosti její národní a konfesijní existence. Postoupit na absolutní úroveň života daného národa předpokládá překročení etno-konfesních hranic onoho národa. V případě židovského národa tkví pochopení pravé podstaty židovství v pochopení duchovního procesu židovského národa, jenž se projevoval ve vnitřních, pozitivních dějinách židovského lidu, o kterých jsme pojednali v předcházející části; především pak v pochopení třech vzájemně provázaných idejích, jenž charakterizují absolutní život národa. Těmito idejemi jsou idea jednoty, idea činu a idea budoucnosti, jenž podle Bubera „reprezentují přrrozené tendence národního charakteru (...), které se projeví takovou silou a takovým trváním, že vytváŕí komplex duševních děl a hodnot, které můžeme nazvat absolutním životem národa“ (Buber 1912, 42). První ideou je tzv. idea jednoty, o které Buber pojednal ve své druhé řeči a není potřebné ji tedy rozvádět dál. Další dvě, tedy idea činu a idea budoucnosti pak jasně dokládají existenciální rozměr Buberovy náboženské filozofie. 
Idea činu se má v duchovním procesu hledání podstaty židovství projevit důrazem na vykonané činy a skutky. Buber se dovolává znovuzrození židovské religiozity, která klade důraz na činy věřících, ale už neklade takový důraz na dodržování normativních zásad věrouky. Navzdory tomu, že se Buber nikdy za Chasida neoznačil, je zřejmé, že je to odkaz tohoto učení, jež nabízí naplnění idey činu židovského národa. Jak Buber uvádí „pro chasidismus není nejdůležitějš́ to, co odjakživa bylo, nýbrž to, co se neustále děje; a sice nikoli to, co se člověku prrihodí, ale to co člověk činí; ne výjimečné, nýbrž obvyklé; a spíše než co dělá, jak to dělá“ (Buber 1963, 804 - 805). Buberova charakteristika chasidismu v podstatě popisuje základní naratív idey činu $\mathrm{v}$ procesu židovské obnovy, který má přivést židovský národ k absolutnímu prožívání života.

Poslední idea, která je propojením předešlých dvou a která přinese absolutní existenci židovského národa, je spjata s ideou budoucnosti. Tato idea je v charakteru židovského národa vyjádřena „,větším důrazem na čas, než prostor“ (Buber 1912, 49). Vnímaní času znamená pro Židy především asociaci, jenž je propojena s pocitem sounáležitosti s realitou minulých generací. Koncept mesianismu dává Židům permanentní naději na možnou budoucí změnu, vytváří v nich pocit odpovědnosti za následující židovské generace, který se projevuje především ve snaze zabezpečit dostatek materiálních statků (Buber 1912, 50 - 51).

Na závěr je potřebné si uvědomit, že pro Buberův narativ o relativním a absolutním životě národa je zcela zásadní vztah těchto pojmů. Existence relativního života národa není podmíněna dosažením existence absolutního života národa, zatímco existence absolutního stavu národa je závislá na existenci stavu relativního. Buber se dovolával obnovy židovství skrze personální uskutečnění výše zmíněných idejí, př̌ičemž požadoval radikální a rychlou proměnu židovství, nikoliv změnu postupnou, evoluční.

\section{Literatura}

BIZOŇ, M. (2014): O „vzájomnosti“a vzt’ahu Ja - Ty u Martina Bubera. Filozofia, 69 (7), 569 - 580. BIZON, M. (2016): Buberova otázka jedincovi. Filozofia, 71 (4), $304-315$.

BIZOŇ, M. (2017): Vzájomnost' medzi Ja a Ty. Dialogická filozofia Martina Bubera. Trnava: UCM v Trnave.

BRODY, S. (2018): Martin Buber's Theopolitics. Bloomington: Indiana University Press.

BUBER, M. (1900): Jüdische Rennaisance. In: Buber, M.: Die Jüdische Bewegung. Gesammelte aufsätze und ansprachen 1900 - 1915. Berlin: Jüdischer Verlag.

BUBER, M. (1901): Gegenwartsarbeit. In: Buber, M.: Die Jüdische Bewegung. Gesammelte aufsätze und ansprachen 1900 - 1915. Berlin: Jüdischer Verlag.

BUBER, M. (1902): Die Schaffenden, das Volk und die Bewegung. In: Buber, M.: Die Jüdische Bewegung. Gesammelte aufsätze und ansprachen 1900 - 1915. Berlin: Jüdischer Verlag.

BUBER, M. (1903): Rennaisance und Bewegung. In: Buber, M.: Die Jüdische Bewegung. Gesammelte aufsätze und ansprachen 1900 - 1915. Berlin: Jüdischer Verlag.

BUBER, M. (1903a): Zionistiche Politik. In: Buber, M.: Die Jüdische Bewegung. Gesammelte aufsätze und ansprachen 1900 - 1915. Berlin: Jüdischer Verlag. 
BUBER, M. (1904): Theodor Herzl. In: Buber, M.: Die Jüdische Bewegung. Gesammelte aufsätze und ansprachen 1900 - 1915. Berlin: Jüdischer Verlag.

BUBER, M. (1904a): Herzl und die Historie. In: Buber, M.: Die Jüdische Bewegung. Gesammelte aufsätze und ansprachen 1900 - 1915. Berlin: Jüdischer Verlag.

BUBER, M. (1912): Tři řeči o židovství. Praha: Spolek židovských akademiků Theodore Herzl.

BUBER, M. (1948): Israel and the World: Essays in Time of Crisis. New York: Schocken.

BUBER, M. (1963): Die chassidische Botschaft. In: Buber, M.: Werke: Schriften zum Chassidismus. Heidelberg: Verlag Lambert Schneider

BUBER, M. (1973): On Zion: the History of an Idea. New York: Schocken.

BUBER, M. (1994): Život Chasidiu. Praha: Arbor Vitae.

GLATZER, N., MENDES-FLOHR, P. (1991): The Letters of Martin Buber. A Life of Dialogue. New York: Schocken Books.

HA“AM, A. (1962): The Jewish State and the Jewish Problem. In: Kohn, H. (ed.): Nationalism and the Jewish Ethic. New York: Schocken Books.

HERZL, T. (2009): Židovský stát: pokus o moderní řešení židovské otázky. Praha: Academia.

KIEVAL, J. H. (2011): Formováni českého židovstva. Národnostni konflikt a židovská společnost v Čechách 1870 - 1918. Praha: Paseka.

MENDES-FLOHR, P. (2019): Martin Buber. A Life of Faith and Dissent. New Haven: Yale University Press.

POLÁKOVÁ, J. (1993): Filosofie dialogu: uvedeni do jednoho z proudi̊ filosofického myšleni 20. století. Praha: Filozofický ústav AVČR.

POLÁKOVÁ, J. (1995): Filosofie dialogu: (Rosenzweig, Ebner, Buber, Lévinas). Praha: Ježek.

SHONKOFF, S. (ed.) (2018): Martin Buber: His Intellectual and Scholarly Legacy. Boston: Brill.

ŠAJDA, P. (2011): Martin Buber: „No - One Can so Refute Kierkegaard as Kierkegaard Himself“. In: STEWART, J.: Kierkegaard and Existentialism (Kierkegaard Research: Sources, Reception and Resources, zv. 9). Aldershot: Ashgate.

ŠAJDA, P. (2013): Buberov spor s Kierkegaardom: O vztahu náboženstva k etike a politike. Bratislava: Kalligram.

ŠAJDA, P. (2013a): Kierkegaardov príspevok k Buberovej filozofii židovstva, teórii vlastenectva a teórií politických skupín. Filozofia, 68 (1), 5 - 16.

ŠAJDA, P. (2020): The Double Wave of German and Jewish Nationalism: Martin Buber's Intellectual Conversion. Human Affairs, 30 (2), 269 - 280. DOI: https://doi.org/10.1515/humaff2020-0024.

Tato studie vznikla díky grantové podpoře projektu FF_IGA_2019_036: Sionismus, Neo-sionismus, Post-sionismus, který je řešen na Katedře politologie a evropských studií Univerzity Palackého v Olomouci.

L’ubomír Zvada

Katedra politologie a evropských studií

Filozofická fakulta

Univerzita Palackého v Olomouci

Křížkovského 12

77180 Olomouc

Česká republika

E-mail: lubomir.zvada01@upol.cz

ORCID ID: https://orcid.org/0000-0003-0869-5014 